\title{
TOWARDS A SUSTAINABLE OIL SUPPLY: A RISK DIVERSIFICATION MODEL TO MEASURE OIL SECURITY RISK IN JAPAN AND SOUTH KOREA
}

\author{
MING QI \& YUMO YANG \\ School of Business Administration, China University of Petroleum (Beijing), China.
}

\begin{abstract}
This paper proposes a quantitative optimization model to investigate the oil supply risk from the perspective of the diversification of oil import sources. Japan and South Korea are highly dependent on oil imports from foreign countries. Both countries are seeking sustainable strategies to ensure a continuous and stable oil supply. Effective diversification of crude oil imports plays an important role in energy security. The optimization results imply that Japan faces the highest oil import risk. Japan should reduce oil imports from Saudi Arabia and the UAE. Instead, Japan should import more oil from Russia and Iraq. South Korea should reduce its oil dependence on the Persian Gulf countries. Based on forecasts of oil demand and production, Japan and South Korea will have lower oil supply risks until 2035. It can be attributed to the decreased oil imports and improved energy efficiency for both countries under individual energy efficiency programs. The Middle East countries maintain the dominant positions in oil imports for both Japan and South Korea. Saudi Arabia will remain the largest supplier to both countries.

Keywords: diversification, oil security, optimal imports.
\end{abstract}

\section{INTRODUCTION}

The security of the energy supply has gained world-wide attention as a result of concerns about energy depletion and peak oil production [1,2]. The National Conference of State Legislatures (NCSL) [3] has defined Energy Security as a "resilient energy system" which would be capable of withstanding threats through a combination of active (direct) and passive (indirect) security measures. Among all of these concepts, how to maintain a stable oil supply is the most pressing concern for both researchers and policymakers. The reason why oil supply is the focus of energy security can be concluded as "(1) reduction of threats of oil supply and (2) operating in a mode of crisis management" [4]. Figure 1 illustrates the annual oil consumption of Japan and South Korea during the period from 1965 to 2035. Japan ranks as the third largest oil consumer in the world after the U.S. and China. Korea is the world's seventh largest oil consumer and fourth largest oil importer [5]. Despite the declining oil demand, Japan and South Korea maintain a high oil consumption level, which will reach 2500 and 1790 thousand barrels per day (tb/d) by 2035, respectively [6]. As a result of limited domestic oil reserves, almost all of the oil supply of Japan and South Korea is based on foreign imports. Japan and South Korea are highly dependent on oil imports from foreign countries $[2,8]$. A secure and stable oil supply plays an essential role in promoting continuous future economic growth. They are seeking strategies to ensure a continuous and stable oil supply from exporting countries. It is crucial to establish an optimal combination of oil supply sources that can improve the energy security of both countries. Although many energy security assessment instruments and statistical indicators have been elaborated in previous research, there exists little work which use quantitative method to provide detailed oil import diversification plans for oil-importing countries. The main contribution of this paper is to propose a quantitative optimization model to investigate the oil supply risk from the 


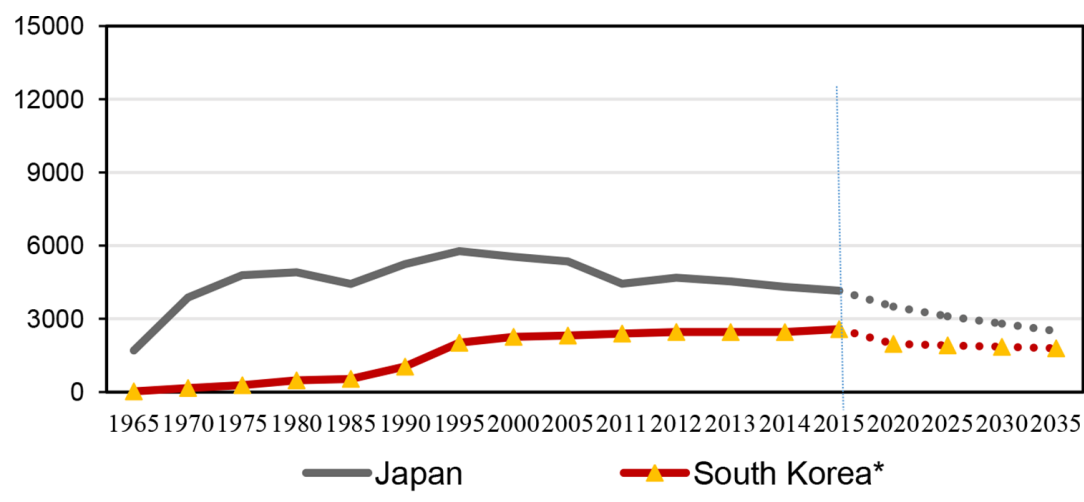

Source: "BP Statistics (2016)", IEA "World Energy Outlook (2015)" and "Oil Supply Security: Emergency Response of IEA Countries 2011: Korea (Republic of)". The dashed lines stand for the forecast values. Unit: thousand barrels per day

* The oil consumption of South Korea in 2025 and 2030 are estimated by the author using linear estimation method.

Figure 1: Annual oil consumption by country.

perspective of the diversification of oil import sources. Based on the decomposition of risk measure by each oil-importing country, the optimal oil import strategies are suggested for Japan and South Korea.

\section{LITERATURE REVIEW}

A large body of research has been devoted to the risk exposure against a reliable energy supply. Vivoda [9, 10] elaborate on the importance of supply diversification to the energy security policies and proposes a novel "energy security assessment instrument". Different approaches are proposed to forecast the country risk of major oil exporting countries, such as Ensemble Empirical Mode Decomposition (EEMD) and Decomposition Hybrid Approach (DHA) [11, 12]. Oil-producing countries also tend to diversify their export structure. The greater the number of years, the higher the degree of export diversification ceteris paribus [13]. In extant researches, many studies document the levels of heterogeneity among the energy diversification strategies. Various indices are proposed to evaluate the energy security, such as physical energy supply risk, principle component technique (PCT), Aggregated Energy Security Performance Indicator (AESPI), Energy Security Price Index (ESPI), Energy Security Physical Availability Index (ESPAI), Risky External Energy Supply (REES) and Countryspecific Diversification Index (CDI) [7, 14-18].

There have been numerous researches focusing on energy security from the perspective of supplier diversification. He et al. [19] include the share of oil exports to annul oil production for an oil-supplying country in measuring the risk and diversification effect of oil supply security. Wu et al. [20] and Li et al. [21] used improved portfolio approach and multi-objective programming approach to quantify the diversification index of China's crude oil imports, respectively [20,21]. The country risk of oil exporting countries is a significant issue $[2,8]$. Compared with China, EU and US, Japan faces higher risks since the country has the highest oil import dependency [22]. Atsumi [23] investigates the government interference on Japan's energy security and argues that eliminating the political dimension of energy security would strengthen the market characteristics of crude oil. Japan's oil import policy has reduced systematic risks, although the oil imports strategy is more concerned on potential exports than 
country risk [24, 25]. A higher level of energy cooperation among East Asian countries would benefit Japan [26, 27]. Bustelo [28] and Kim et al. [29] analyze the primary energy consumption and energy strategies of Japan and South Korea based on several policy-based scenarios. The findings provide some lessons from the experiences of Japan and South Korea.

\section{METHODOLOGY AND DATA DESCRIPTION}

\subsection{The model}

The composition of import suppliers plays a significant role in determining the oil supply risk of an individual country $[9,16,18]$. Notably, Japan and South Korea all heavily depend on external oil imports. Well-diversified oil supply portfolio provides a greater resilience against supply shocks. Following Cohen et al. [16] and He et al. [19], the risk measure (Z) is defined as the product of the diversification index and country specific factors. In order to improve the oil supply security and obtain the optimal oil import strategies, the risk measure is minimized. The optimization is performed subject to three functions. First, the total amount of oil supply should meet domestic oil demand. Second, the total amount of oil supply should satisfy the refinery capacity. Last, the oil imports cannot over the production level of the exporting country. The model is as follows:

$$
\begin{array}{cr}
\min _{q_{i j}} Z_{j}=\sum_{i}\left[\left(\frac{q_{i j}}{Q_{j}}\right)^{2} \cdot\left(\frac{Q_{j}}{D_{j}}\right) \cdot r_{i} \cdot\left(\frac{q_{i j}}{Q e_{i}}\right) \cdot 1000\right] & \text { objective function (1) } \\
\text { s.t. } \frac{\sum_{i} q_{i j}}{W_{j}}+P_{j} \geq D_{j} & \text { demand constraint (2) } \\
\frac{\sum_{i} q_{i j}}{W_{j}}+P_{j} \leq R_{j} & \text { refinery constraint (3) } \\
0 \leq q_{i j} \leq Q_{j} & \text { non-negativity constraint (4) }
\end{array}
$$

Where $Z_{j}$ denotes the oil supply risk measure of country $j, q_{i j}$ is the crude oil imports from the exporting country $i$ to the importing country $j$. For illustration purposes, the risk measures are scaled up 1000 times to make the following figures more obvious. $Q_{j}$ and $Q e_{i}$ stand for the total oil imports of country $j$ and the total oil production of country $i$, respectively. Following [18], the Herfindahl-Hirschman index (HHI) is used, measured as $\sum_{i}\left(\frac{q_{i j}}{Q_{j}}\right)^{2}$, to evaluate the diversification of oil imports. $P_{j}$ and $D_{j}$ denote the domestic oil production and total oil demand of country $j$, respectively. $\frac{Q_{j}}{D_{j}}$ denotes the external dependency of oil importing country $j \cdot \frac{q_{i j}}{Q \mathrm{e}_{i}}$ stands for the ratio of oil trade between countries $i$ and $j$ to annual oil production of country $i$. 
The diversification strategy of an exporting country is also necessary [19]. An oil supplier with a portfolio with a relatively low degree of concentration has a smaller trading risk. If an oil consuming country imports a large proportion of oil from an individual country, the oil consumption country is exposed to higher supply shocks. In other words, if the oil imports to country $j$ account for a smaller proportion of the total production $t$ supplier, it is less likely for country $j$ to be influenced by a possible oil reduction of country $i$. The country risk index, denoted as $r_{i}$, is used to measure a country's security situation. The International Country Risk Guide (ICRG) rating is a widely accepted country risk measure [18, 27, 29, 30]. However, the ICRG composite risk index is based on a $(0,100)$ scale, where a high score indicates low country risk. To make the risk index compatible with the optimization model, the country risk index $r_{i}$ is instead defined as follows:

$$
r_{i}=100-I C R G_{-} R i s k_{i}
$$

where $I C R G_{-}$Risk $_{i}$ is the original composite risk rating based on the ICRG $\mathrm{f}$ each oil exporting country $i$. After the transformation, $r_{i}$. remains on the $(0,100)$ scale, but high values are associated with the high country risk of country $i$. Thus the product of $\left[r_{i} \cdot\left(\frac{q_{i j}}{Q e_{i}}\right)\right]$ can be explained as the Sustainable Availability Index (SAI) of oil. A higher value of SAI implies that the exporting country $i$ bears a higher risk in torld oarket. The imports from country $i$ are more vulnerable to the production shock. Under the demand constrain of equation (2), the sum of domestic oil production and external imports of each oil-importing country should meet domestic consumption demand. In this model, the top ten suppliers of each country are analyzed. In 2011, the crude oil from the top ten supplying countries accounted for almost $91 \%$ and $94 \%$ of total oil imports to Japan and South Korea, respectively. This results in our sample are then representative to outline the energy import strategies.

The common supply risks of Japan and South Korea are minimized. Here, $w_{j}$ is used to denote the percentage of oil imports from the top ten supplying countries to the total oil imports of country $j$. On the other hand, the sum of domestic oil production and external imports of each oil-importing country should satisfy the refinery capacity, as shown in the refinery constraint. Finally, the value of oil imports from each supplying country must be positive and cannot exceed the total volume of oil imports, as shown in the nonnegativity constraint. The Non Linear Optimization model is programmed in GAMS and solved by CONOPT, which is a standard solver for the Non-Linear Programming (NLP) algorithm. This model can be extended to analyze other resource supply risks except the crude oil.

\subsection{Data description}

The oil imports statistics and forecasted crude oil consumption data for Japan comes from BP statistics 2016 and World Energy Outlook (2015) by the IEA [6, 31]. The forecasts of South Korea's oil consumption from "Oil and Gas Emergency Policy -Korea (2011 updated)" [32]. The forecasting data of OPEC crude oil production is collected from World Energy Outlook 2015 under the low oil price scenario [6]. The production levels of the non-OECD countries of Oman, Sudan, Indonesia, Gabon and Australia are estimated through the percentage contribution of each country to the total forecasted production of the country's respective continent. The average of five-year forecasts under the worst case (WC) and the best case 
(BC) are used to proxy the forecasts of composite risk ratings over the entire forecasted period.

\section{CURRENT SITUATION ANALYSIS}

Before presenting the optimal strategies, it is necessary to understand the current oil supply strategies of our sample countries. The most significant feature of current supply strategies is the heavy reliance on oil imports from the Middle East. The crude oil imports and the decomposition of risk measures for Japan and South Korea are shown in figures 2 and 3, respectively. The findings imply that the oil import structures of these two countries are quite similar. Saudi Arabia remains in the dominant position among all of the suppliers. Middle Eastern countries contribute approximately $70 \%$ of the total oil imports of Japan and South Korea. Remarkably, the UAE is the riskiest supplying country in Japan's oil import portfolio. Despite the relatively low country risk of the UAE, the high share of the UAE's exports to its annual oil production explain the country's high risk status within Japan's portfolio. In 2011, more than $20 \%$ of the UAE's crude oil production was exported to Japan.
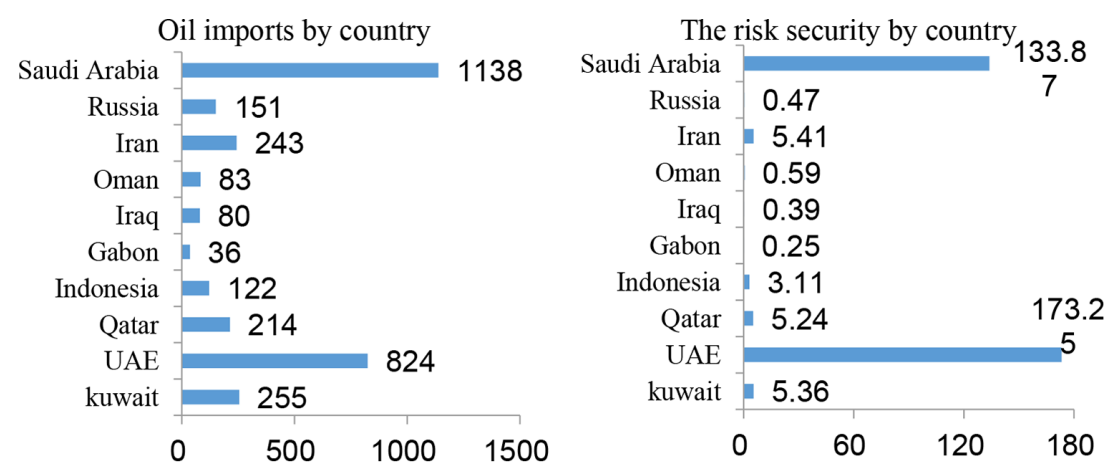

Source: Oil Information (2012 Edition) by IEA. Unit: in thousand barrels per day(tb/d)

Figure 2: Japan's crude imports and the decomposition of risk measure by country (2011).

Oil imports by country

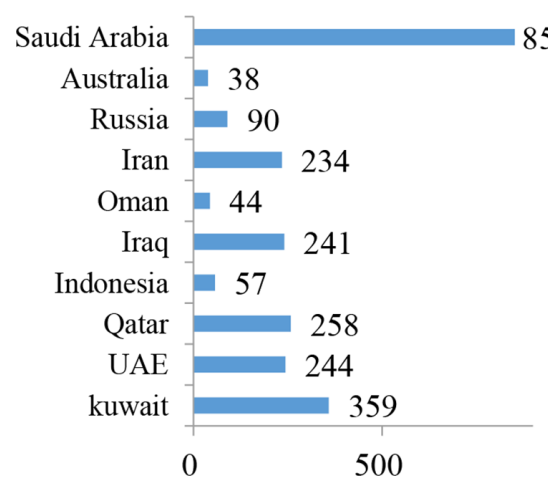

The risk measure by country

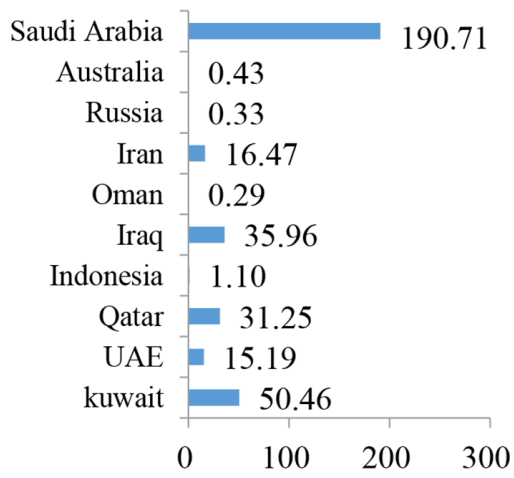

Oil Information (2012 Edition)"by IEA. Unit: in thousand barrels per day(tb/d)

Figure 3: Korea's crude imports and the decomposition of risk measure by country (2011). 
For South Korea, Saudi Arabia has the highest risk measure among all of the suppliers, followed by Kuwait, Iraq and Qatar. It implies that although reducing dependence on Middle Eastern oil has been the primary policy challenge for Japan and South Korea, both countries have achieved very limited success to date. The political and economic stability in the Middle East is of great importance to Japan and South Korea. They concern with Middle Eastern instability is reflected in tghe provision of foreign aid in the forms of loans, grants and technical cooperation.

\section{OPTIMIZATION RESULTS}

\subsection{Optimal Strategies in 2011}

The optimal oil import strategies for Japan and South Korea are shown in Table 1. The results indicate that Japan's optimal risk is much higher than the optimal risks of South Korea. However, Japan has the lowest difference between the current and optimal risk values. This result is in line with the finding that Japan's current oil import policy has significantly reduced the specific and systematic risk of energy security [24]. The results also set forth the optimal strategies for both Japan and South Korea to improve the energy security, as shown in Fig. 4. Japan should considerably reduce crude oil imports from Saudi Arabia and the UAE, while increasing imports from Russia, Iran, Iraq, Kuwait, Qatar and Oman. The optimal strategies are consistent with previous findings which suggests that the diversification is a useful

Table 1: The optimal and current risk measures of Japan and South Korea.

\begin{tabular}{lll}
\hline & Japan & South Korea \\
\hline Optimal & 275 & 161 \\
Current $^{\mathrm{a}}$ & 328 & 342 \\
Difference $^{\mathrm{b}}$ & 47 & 167 \\
\hline
\end{tabular}

a"Current" denotes the risk measure of each country in 2011

b"Difference" is calculated as (Current - Optimal)

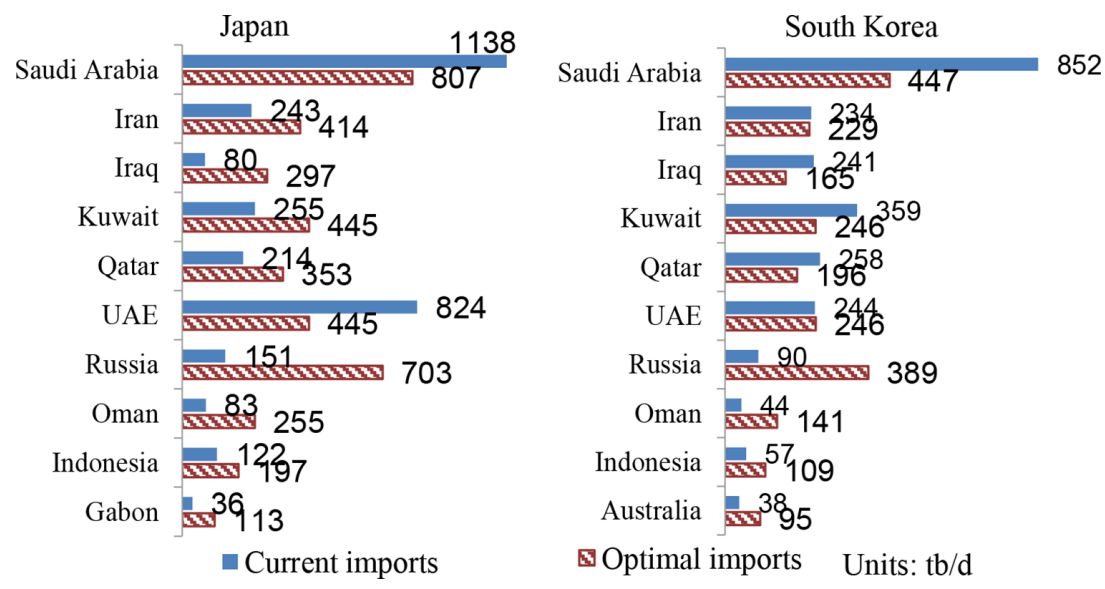

Figure 4: The optimal import strategies for Japan and South Korea 2011. 


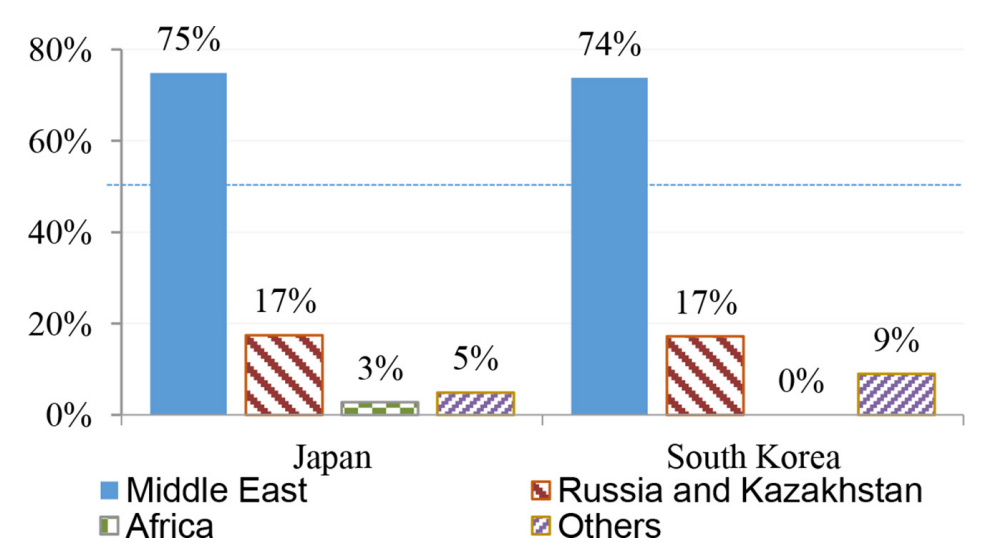

Figure 5: Optimal crude imports by region (2011)

strategy for reducing specific security risks, because it spread the risks of dependence across different supplying countries and regions. By importing alternative energy sources outside the Middle East, Japan has substantially reduced the specific oil import risks [24].

South Korea should reduce the oil reliance on the Middle East countries, especially on Saudi Arabia. South Korea should significantly increase the oil imports from Russian, Indonesia and Australia. This result is in line with previous research which suggests that South Korea's energy policy has been an increasing focus on joint energy projects in Russia. Geographical dispersion of oil imports may improve South Korea's energy security but usually generates higher energy cost. There can be an optimum level of geographic concentration of energy imports [29, 33].

The regional analyses for Japan and South Korea are illustrated in Fig. 5. A noticeable phenomenon is that more than 50 percent of the crude oil imports for both countries come from the Middle East. This result is consistent with the current energy policies of our sample countries. The optimal strategies imply that an even higher proportion of oil imports should come from the Middle East to Japan and South Korea. Apparently, seeking a stable oil supply from the Middle East plays a crucial role in the oil import strategies of both Japan and South Korea. This finding is consistent with the view that imports from Middle East to Asia are expected to increase dramatically [27].

On the other hand, Russia is an important and indispensable supplier to Japan and South Korea, as Russia ranks as the second largest oil supplier to both countries. Russia's exports to Japan surged from 2010 after the Eastern Siberia-Pacific Ocean (ESPO) pipeline was linked to the Russian Far East coast in 2009. The Russian crude oil imports have provided Japan with positive effects the bargaining power in relation to crude suppliers in the Middle East. Finally, because of the relatively high political risk of African countries, the optimal strategy suggests lower crude oil imports from Africa.

\subsection{Strategic perspectives during the forecasted period}

The scenario analyses provide us with an opportunity to forecast future oil supply trends. Based on the forecasts of oil demand and production level, the optimal oil import strategies for Japan and South Korea have shown lower oil supply risks until 2035, as shown in Table 2. It can be attributed to the decreased oil imports and improved energy efficiency for both countries under individual energy efficiency program [34, 35]. The vulnerabilities of Japan's 


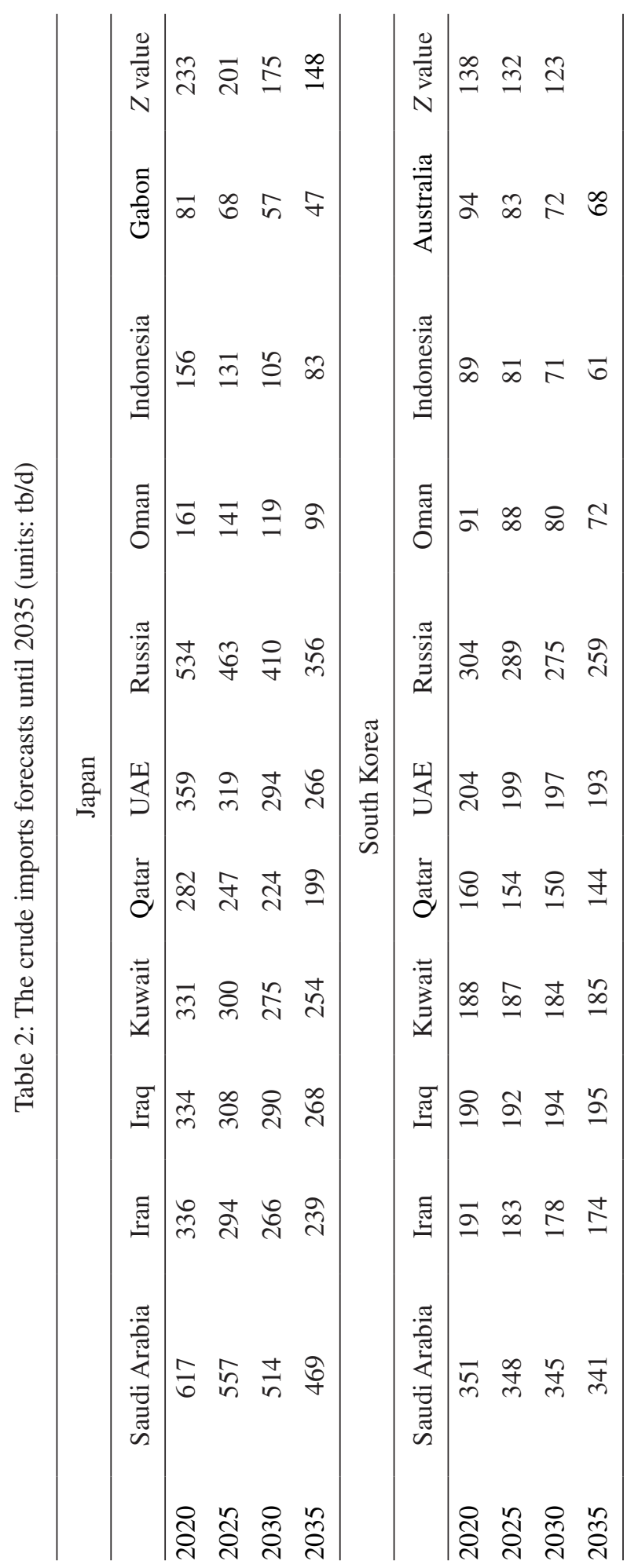


and South Korea's oil supply will continue to decline during the forecasted period. The risk measures of Japan and South Korea will gradually decrease from 258 and 151 in 2011 to 148 and 113 in 2035, respectively. In terms of the regional analysis, the Middle East countries maintain the dominant positions in oil imports for both Japan and Korea. The results suggest that almost 70 percent of the total oil imports will come from the Middle East countries during the forecasted period. This result is in line with previous findings [36, 37]. Saudi Arabia will remain the largest supplier to both countries, followed by Russia, Iraq and the UAE.

This strategy is feasible and consistent with current research findings in two aspects. First, The OPEC Middle East countries will continue to be a dominant group in global oil markets. Saudi Arabia has the largest export capacity in the world [38]. Second, Japan's pro-Arab policy towards the Middle East was governed solely by the interest to secure oil, and did not touch upon political dimensions [37, 39]. On the other hand, the optimal strategy implies that Russia will provide Japan and South Korea with over 15 percent of their total crude imports. This strategy is consistent with previous finding that Russia is considered as the most appropriate additional crude oil supplier to Japan due to its proximity, safety and flexibility. Russia is expected to gain a 10 percent share in the Japanese market in the near future. It will help Japan gain a stronger position in relation to its traditional Middle Eastern oil suppliers [40]. Actually, Japan seeks stable oil supply from Saudi Arabia while competing with China for Russia's Far East oil pipeline projects.

\section{CONCLUSIONS AND LIMITATIONS}

The purpose of this paper is to propose a quantitative optimization model to investigate the oil supply risk, from the perspective of the diversification of oil import sources. The optimization results imply that Middle Eastern countries maintain the dominant positions among all of the suppliers to Japan and South Korea. Suppliers with high country risk measures, such as Angola and Sudan, deteriorate current energy security. Therefore, the effective diversification of imports and stable oil supply play important roles in the energy security. The optimal results of the optimization model indicate that Japan outperforms South Korea in reducing the systematic risk of energy security. In order to reduce the oil supply risk, Japan should reduce oil imports from Saudi Arabia and the UAE, while importing more oil from Russia, Kuwait, Qatar and Oman. The optimal strategy for South Korea is to reduce the oil dependency on Middle Eastern countries, especially on Saudi Arabia. Forecasts of oil consumption and production levels until 2035 are used to analyze the optimal oil import strategy for both countries. As a result of declining oil imports, the oil vulnerability of Japan and South Korea will be gradually reduced during the forecast period. Saudi Arabia remains the largest supplier to both countries, which explains the importance of the Persian Gulf countries to Asian oil supply security.

The findings of this study are subject to several limitations. First, the crude oil price and transportation costs are key issues for energy security. The importing countries must balance off the security, costs and efficiency of crude oil supply. It is quite useful to include these parameters in the optimization. Restricted by the data availability, the oil price and transportation costs are not involved in the analysis. Next, the heterogeneity of crude oil is another important issue. The quality of oil is relevant to not only the oil price, but also the refining configuration. Hence, it is also useful to distinguish the crude oil quality of different exporting counties. 


\section{ACKNOWLEDGEMENT}

This work was supported by Beijing Natural Science Foundation (9164034); Science Foundation of China University of Petroleum, Beijing under Grant 2462013YJRC009.

\section{REFERENCE}

[1] Aleklett, K., Höök, M., Jakobsson, K., Lardelli, M., Snowden, S. \& Söderbergh, B., The peak of the oil age - analyzing the world oil production reference scenario in world energy outlook 2008. Energy Policy, 38(3), pp. 1398-1414, 2010. https://doi.org/10.1016/j.enpol.2009.11.021

[2] Banaszak, S., Chakravorty, U. \& Leung, P.S., Demand for ground transportation fuel and pricing policy in Asian tigers: a comparative study of Korea and Taiwan. The Energy Journal, 20(2), pp. 145-165, 1999. https://doi.org/10.5547/issn0195-6574-ej-vol20-no2-6

[3] Brown, M.H., Rewey, C. \& Gagliano, T. Energy security, The national conference of state legislatures, 2003.

[4] Von Hippel, D., Suzuki, T., Williams, J.H., Savage, T. \& Hayes, P., Energy security and sustainability in Northeast Asia. Energy Policy, 39(11), pp. 6719-6730, 2011. https://doi.org/10.1016/j.enpol.2009.07.001

[5] Kim, H.S. \& Baek, J., Assessing dynamics of crude oil import demand in Korea. Economic Modelling, 35, pp. 260-263, 2013. https://doi.org/10.1016/j.econmod.2013.07.010

[6] IEA, World Energy Outlook 2015. International Energy Agency, Paris, France, 2015.

[7] Gupta, E., Oil vulnerability index of oil-importing countries. Energy Policy, 36(3), pp. 1195-1211, 2008. https://doi.org/10.1016/j.enpol.2007.11.011

[8] Marquez, J., Long-period trade elasticities for Canada, Japan, and the United States. Review of International Economics, 7(1), pp. 102-116, 1999. https://doi.org/10.1111/1467-9396.00149

[9] Vivoda, V., Diversification of oil import sources and energy security: A key strategy or an elusive objective? Energy Policy, 37, pp. 4615-4623, 2009. https://doi.org/10.1016/j.enpol.2009.06.007

[10] Vivoda, V., Evaluating energy security in the Asia-Pacific region: a novel methodological approach. Energy Policy, 38, pp. 5258-5263, 2010. https://doi.org/10.1016/j.enpol.2010.05.028

[11] Li, J.P., Tang, L., Sun, X.L., Yu, L.A., He, W. \& Yang, Y.Y., Country risk forecasting for major oil exporting countries: a decomposition hybrid approach, Computers \& Industrial Engineering, 63, pp. 641-651, 2012. https://doi.org/10.1016/j.cie.2011.12.003

[12] Tang, L., Wang, S. \& Yu, L., EEMD-LSSVR-based decomposition-and-ensemble methodology with application to nuclear energy consumption forecasting. In Computational Sciences and Optimization 2011 Fourth International Joint Conferences, pp. 589-593, 2011.

[13] Omgba, L.D., Institutional foundations of export diversification patterns in oilproducing countries. Journal of Comparative Economics, 42, pp. 1052-1064, 2014. https://doi.org/10.1016/j.jce.2014.02.001 
[14] Frondel, M. \& Schmidt, C.M., A measure of a nation's physical energy supply risk. The Quarterly Review of Economics and Finance, 54, pp. 208-215, 2014. https://doi.org/10.1016/j.qref.2013.10.003

[15] Martchamadol, J. \& Kumar, S., The aggregated energy security performance indicator (AESPI) at national and provincial level. Applied Energy, 127, pp.219-238, 2014. https://doi.org/10.1016/j.apenergy.2014.04.045

[16] Cohen, G., Joutz, F., Loungani, P., Measuring energy security: Trends in the diversification of oil and natural gas supplies, Energy Policy, 39, pp. 4860-4869, 2011. https://doi.org/10.1016/j.enpol.2011.06.034

[17] Lefèvre, N., Measuring the energy security implications of fossil fuel resource concentration. Energy Policy, 38, pp. 1635-1644, 2010. https://doi.org/10.1016/j.enpol.2009.02.003

[18] Le Coq, C., Measuring the security of external energy supply in the European Union. Energy Policy, 37, pp. 4474-4481, 2009. https://doi.org/10.1016/j.enpol.2009.05.069

[19] He, W., Sun, X., Tang, L. \& Li, J., Modeling on Oil-Importing Risk under Risk Correlation, in: Proceedings of 2009 international joint conference on computational sciences and optimization, part 2. IEEE, Computer Society CPS, pp. 434-438, 2009.

[20] Wu, G., Wei, Y.M., Fan, Y. \& Liu, L.C., An empirical analysis of the risk of crude oil imports in China using improved portfolio approach. Energy Policy, 35, pp. 4190-4199, 2007. https://doi.org/10.1016/j.enpol.2007.02.009

[21] Li, J., Tang, L., Sun, X. \& Wu, D., Oil-importing optimal decision considering country risk with extreme events: a multi-objective programming approach. Computers \& Operations Research, 42, pp.108-115, 2014. https://doi.org/10.1016/j.cor.2011.10.010

[22] van Moerkerk, M. \& Crijns-Graus, W., A comparison of oil supply risks in EU, US, Japan, China and India under different climate scenarios. Energy Policy, 88, pp.148-158, 2016. https://doi.org/10.1016/j.enpol.2015.10.015

[23] Atsumi, M., Japanese energy security revisited. Asia-Pacific Review, 14, pp. 28-43, 2007. https://doi.org/10.1080/13439000701330353

[24] Lesbirel, S.H., Diversification and energy security risks: the Japanese case. Japanese Journal of Political Science, 5, pp. 1-22, 2004. https://doi.org/10.1017/s146810990400129x

[25] Yang, Y., Li, J., Sun, X. \& Chen, J., Measuring external oil supply risk: a modified diversification index with country risk and potential oil exports. Energy, 68, pp.930-938, 2014. https://doi.org/10.1016/j.energy.2014.02.091

[26] Kashcheeva, M. \& Tsui, K., The effects of international politics on oil-exporting developing countries, IDE Discussion Papers 459, Institute of Developing Economies, Japan External Trade Organization, 2014.

[27] Toichi, T., Energy security in Asia and Japanese policy. Asia-Pacific Review, 10, pp. 44-51, 2003.

https://doi.org/10.1080/13439000301608 
[28] Bustelo, P., Energy security with a high external dependence: the strategies of Japan and South Korea. University Library of Munich, 2008.

[29] Kim, H., Shin, E.S. \& Chung, W.J., Energy demand and supply, energy policies, and energy security in the Republic of Korea. Energy Policy, 39, pp. 6882-6897, 2011. https://doi.org/10.1016/j.enpol.2011.07.056

[30] International Country Risk Guide. The PRS Group, New York, 2012.

[31] BP Statistic Review of World Energy. BP, London, 2016.

[32] IEA, Oil and Gas Emergency Policy - Korea 2011 update. International Energy Agency, Paris, France, 2011.

[33] Ma, P., Jiang, H. \& Hong, Y., Geographic concentration of Korean oil imports and the implications. Advanced Materials Research, 608, pp. 1506-1510, 2013. https://doi.org/10.4028/www.scientific.net/amr.608-609.1506

[34] Tsunoda, M., Japan country report in Kimura. Energy Outlook and Energy Saving Potential in East Asia 2016, Jakarta: ERIA, pp. 163-175, 2016.

[35] Lee, W.N., Kim, H.J., Park, J.B., Roh, J.H. \& Cho, K.S., An economic evaluation of the energy efficiency programs in Korea. Journal of International Council on Electrical Engineering, 2, pp. 219-224, 2012. https://doi.org/10.5370/jicee.2012.2.2.219

[36] Levkowitz, A., Korea and the Middle East turmoil: a reassessment of South KoreaMiddle East relations. The Korean Journal of Defense Analysis, 24, pp. 225-238, 2012.

[37] Shimizu, M., Japan's Middle East policy. Japan Quarterly, 35, p. 383, 1998.

[38] Matsumoto, K.I., Voudouris, V., Stasinopoulos, D., Rigby, R. \& Di Maio, C., Exploring crude oil production and export capacity of the OPEC Middle East countries. Energy policy, 48, pp.820-828, 2012. https://doi.org/10.1016/j.enpol.2012.06.027

[39] Kimura, S., Japan's Middle-East policy: impact of the oil crisis. Kobe University Law Review, 19, p. 24, 1985.

[40] Motomura, M., Japan's need for Russian oil and gas: a shift in energy flows to the Far East. Energy Policy, 74, pp. 68-79, 2014. https://doi.org/10.1016/j.enpol.2014.08.024 